\title{
Mushroom bodies of the honeybee brain show cell population-specific plasticity in expression of amine-receptor genes
}

\author{
H. James McQuillan, Shinichi Nakagawa, and Alison R. Mercer ${ }^{1}$ \\ Department of Zoology, University of Otago, Dunedin 9054, New Zealand
}

\begin{abstract}
Dopamine and octopamine released in the mushroom bodies of the insect brain play a critical role in the formation of aversive and appetitive memories, respectively. As recent evidence suggests a complex relationship between the effects of these two amines on the output of mushroom body circuits, we compared the expression of dopamine- and octopamine-receptor genes in three major subpopulations of mushroom body intrinsic neurons (Kenyon cells). Using the brain of the honeybee, Apis mellifera, we found that expression of amine-receptor genes differs markedly across Kenyon cell subpopulations. We found, in addition, that levels of expression of these genes change dramatically during the lifetime of the bee and that shifts in expression are cell population-specific. Differential expression of amine-receptor genes in mushroom body neurons and the plasticity that exists at this level are features largely ignored in current models of mushroom body function. However, our results are consistent with the growing body of evidence that short- and long-term olfactory memories form in different regions of the mushroom bodies of the brain and that there is functional compartmentalization of the modulatory inputs to this multifunctional brain center.
\end{abstract}

Mushroom bodies (MBs) of the insect brain play a critical role in the formation and recall of associative olfactory memories (for reviews, see Menzel 2001; Heisenberg 2003; Davis 2005; Keene and Waddell 2007). During aversive learning, dopamine (DA) released at this level conveys the reinforcing properties of aversive stimuli (Schwärzel et al. 2003; Riemensperger et al. 2005; Schroll et al. 2006; Vergoz et al. 2007; Claridge-Chang et al. 2009). Food rewards, on the other hand, activate modulatory neurons that release octopamine $(\mathrm{OA})$, which supports the formation of appetitive memories in the insect brain (Menzel and Müller 1996; Hammer and Menzel 1998; Menzel et al. 1999; Schwärzel et al. 2003; Schroll et al. 2006; Honjo and Furukubo-Tokunaga 2009). Interestingly, abnormal expression of the Drosophila DA receptor dDA1 not only impairs aversive learning but also appetitive learning (Kim et al. 2007), and in bees and flies, appetitive memory recall can be suppressed by DA (Mercer and Menzel 1982; Krashes et al. 2009). Treatment with OA has recently been shown also to reduce avoidance learning behavior in the bee (Agarwal et al. 2011). These results suggest a complex interplay between the effects of DA and OA on MB circuits and ultimately on learning performance, but the nature of this interplay remains unclear. To begin to address this issue, we have examined in this study patterns of expression of DA and OA receptor genes in MBs of the honeybee, Apis mellifera.

MB intrinsic neurons (Kenyon cells) in the honeybee express three DA-receptor genes, Amdop1 (Blenau et al. 1998; Kurshan et al. 2003), Amdop2 (Humphries et al. 2003; Kurshan et al. 2003), and Amdop3 (Beggs et al. 2005). To date, only one OA receptor gene, Amoa1, has been characterized and identified in this region of the brain (Grohmann et al. 2003); however, several putative OA receptors have been identified in the honeybee genome (Hauser et al. 2006) and are currently being characterized. Amdop1, Amdop2, and Amoa1 code for G-protein-coupled recep-

${ }^{1}$ Corresponding author.

E-mail alison.mercer@otago.ac.nz.

Article is online at http://www.learnmem.org/cgi/doi/10.1101/Im.025353.111. tors that increase intracellular levels of cAMP when activated (Blenau et al. 1998; Grohmann et al. 2003; Humphries et al. 2003; Mustard et al. 2003, 2005; Beggs and Mercer 2009), whereas activation of the $A m D O P 3$ receptor generally reduces intracellular levels of cAMP (Beggs et al. 2005; Clark and Baro 2007; Beggs and Mercer 2009). Increases in cAMP levels resulting from AmDOP3 receptor activation can be observed also under some conditions (Clark and Baro 2007), and AmOA1 receptors and the dopamine receptor, $A m D O P 2$, signal not only via cAMP but also through changes in intracellular $\mathrm{Ca}^{2+}$ (Grohmann et al. 2003; Beggs et al. 2011).

The diversity of receptor types mediating the effects of DA and $\mathrm{OA}$ in the insect brain suggests that responses to these amines will vary depending on the complement of receptors expressed by target cells. As differential expression of amine-receptor genes in MB neurons could have important functional implications, we compared the levels of DA- and OA-receptor gene expression in three major subpopulations of MB Kenyon cells and examined the extent to which shifts in the expression of amine-receptor genes in this important learning and memory center are cell population-specific.

\section{Results}

Age-related changes in amine-receptor gene expression In whole-brain samples, significant shifts in expression levels were identified for Amdop1 (Fig. 1A), Amdop2 (Fig. 1B), Amdop3 (Fig. 1C), and Amoa1 (Fig. 1D). Data were normalized using Rpn2 and Rps8 (see Fig. 2B,C), but similar results were also obtained when $18 \mathrm{~S}$ was used as an alternative stable reference gene (Fig. 1E-H). Data obtained for candidate reference genes tested are shown in Figure 2. Each of the amine-receptor genes examined in this study exhibited a unique expression profile. Post hoc analyses revealed that levels of Amdop1 mRNA in whole-brain samples were significantly lower in 15-d-old bees than in adult bees of all other ages examined (Fisher's least significant difference [LSD], $P<0.05$ ) 

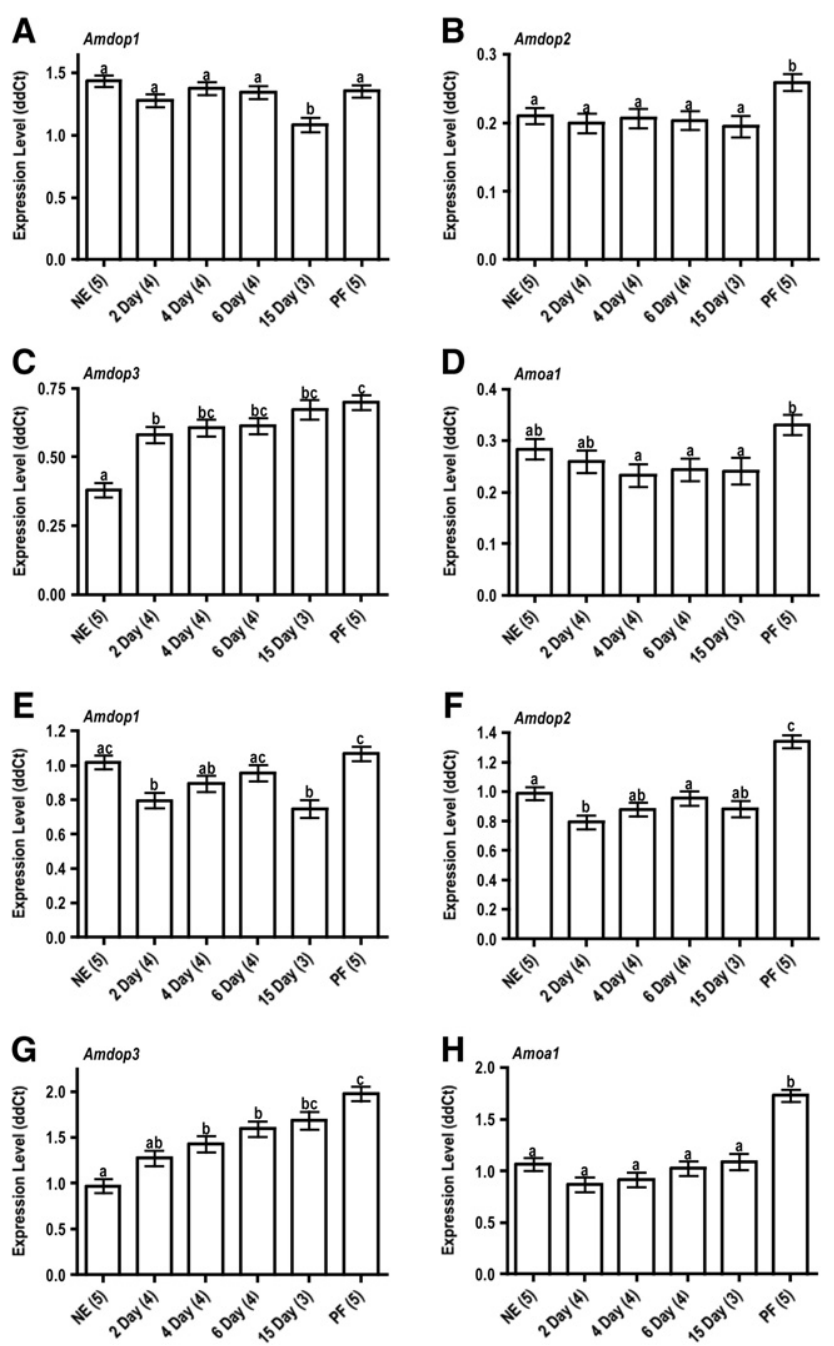

Figure 1. Amine-receptor gene expression levels in the adult bee brain from emergence to foraging age. $(A-D)$ Expression levels normalized using the geometric mean of Rpn2 and Rps8. Statistics (LMM): Amdop1, age $P<0.0001 ;$ Amdop2, age $P<0.0001$; Amdop3, age $P<0.0001$; Amoa1, age $P<0.0001$. $(E-H)$ Data normalized using 18S. Statistics (LMM): Amdop1, age $P<0.0001$; Amdop2, age $P<0.0001$; Amdop3, age $P<0.0001$; Amoa 1 , age $P<0.0001$. Bars that do not share a letter differ significantly (Fisher's LSD, $P \leq 0.05$ ). Data are presented as mean \pm standard error. Numbers in parentheses indicate sample size. (NE) Newly emerged bees, (PF) pollen foragers.

(Fig. 1A). Amdop2 transcript levels, on the other hand, were remarkably stable over the first $15 \mathrm{~d}$ of adult life but were significantly higher in whole-brain samples from pollen foragers than in all of the other groups examined (Fisher's LSD $P<0.05$ ) (Fig. 1B). Levels of expression of Amdop3 in the brain increased significantly during the first $2 \mathrm{~d}$ of adult life (linear mixed-effects model $[\mathrm{LMM}], P<0.001)$ and were higher in pollen forager bees when compared to 2 -d-olds $(P<0.05)$ but did not show an obvious change correlated with foraging (Fig. 1C). Overall, the expression profile of Amoa1 was most similar to that of Amdop2 (cf. Fig. 1, B and D); levels of expression of Amoa1 in the brains of 4-, 6- and 15-d-olds were significantly lower than the level detected in the brains of pollen foragers (Fisher's LSD, $P<0.05$ ).

Similar changes in receptor-gene expression were apparent also in the brains of bees collected and analyzed the following summer (Fig. 3A-D). Consistent with the data set collected during the first summer, we found no significant differences in levels of Amdop1 expression between newly emerged (NE) bees, 6-d-olds, and pollen foragers (Fig. 3A). Based on the first data set, we predicted also that levels of expression of Amdop 2 and Amoa1 would be higher in the brains of pollen foragers than in 6-d-old bees. While this prediction held true for Amoa1 (Fisher's LSD, $P<$ 0.05) (Fig. 3D), it did not hold true for Amdop2. In the second data set, the level of expression of Amdop2 in pollen foragers was similar to that detected in 6-d-olds (Fig. 3B). In brain samples collected during the second summer, as in the first, expression of Amdop3 was significantly higher in the brains of 6-d-olds than in NE bees (Fisher's LSD, $P<0.05$ ) (Fig. 3C). The level of Amoa1 expression detected in the brains of 6-d-olds was significantly lower than the level detected in NE bees (Fisher's LSD, $P<0.05$ ) (Fig. $3 \mathrm{D})$, a result that was also consistent with trends apparent in the first data set.

\section{Amine-receptor gene expression in MB Kenyon cells}

The analyses outlined above revealed significant changes in amine-receptor gene expression in the brain, not only early in adult life but also correlated with a transition to duties outside the colony (pollen foraging). For this reason, we conducted two independent experiments to look for changes in levels of receptorgene expression in subpopulations of MB neurons. To reveal potential shifts in gene expression occurring early in adult life, we compared levels of amine-receptor gene expression in NE bees and 15-d-olds (Fig. 4). To examine changes in gene expression that may be associated with the transition from duties within
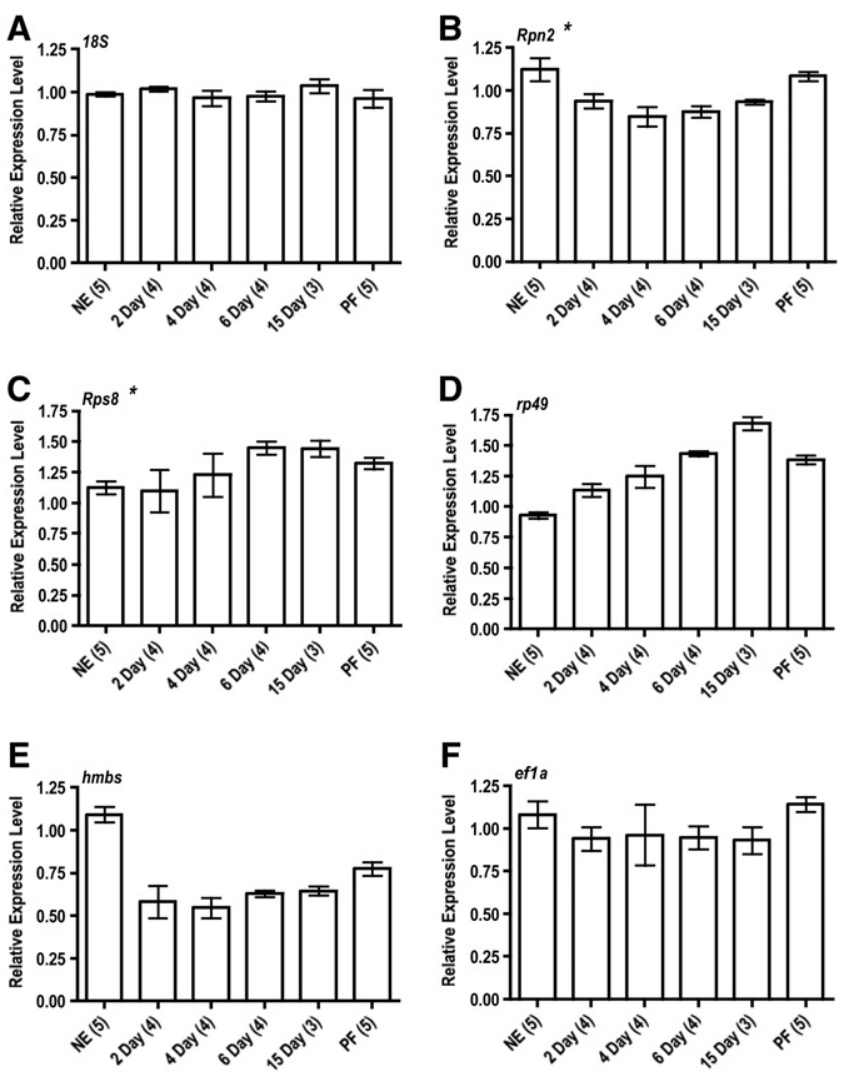

Figure 2. Levels of expression in the brain of candidate reference genes. Bars indicate means \pm standard error. Numbers in parentheses indicate sample size. Asterisks indicate the most stable pair of genes as determined using Normfinder. Rpn2 and Rps 8 were used to normalize gene expression levels in this study. (NE) Newly emerged bees, (PF) pollen foragers. 

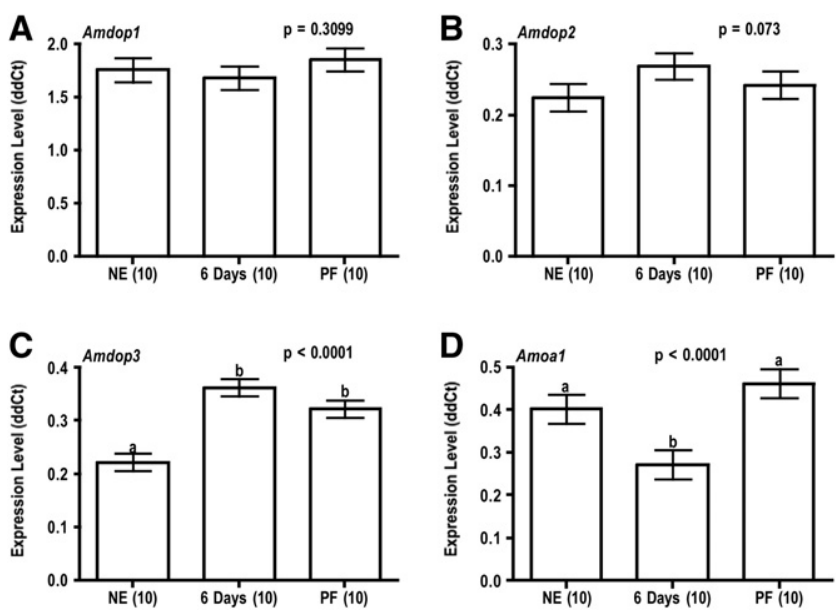

Figure 3. Amine-receptor gene expression levels in the adult bee brain of newly emerged bees (NE), 6-d-olds, and pollen foragers (PF). Statistics (LMM): (A) Amdop1, age $P<0.3099 ;(B)$ Amdop2, age $P=0.073$; (C) Amdop3, age $P<0.0001 ;(D)$ Amoa1, age $P<0.0001$. Letters above the bars indicate the significance of differences between groups. Bars that do not share a letter differ significantly (Fisher's LSD, $P \leq 0.05$ ). Bars indicate the mean \pm standard error. Numbers in parentheses indicate sample size.

the hive to foraging, we compared expression levels in 6-d-olds with levels detected in pollen foragers (Fig. 5). As in situ hybridization analysis (Fig. 6) suggested to us that the genes of interest are differentially expressed across the three major subpopulations of Kenyon cells in the honeybee (Fig. 6A-D), we compared (where possible) levels of expression in all three cell types. Consistent with the terminology introduced by Farris et al. (2004), we refer to these Kenyon cell populations as outer compact cells (OCC), innercompact cells (ICC), and noncompact cells (NCC) (see Fig. 6Ai).

\section{Shifts in gene expression early in adult life}

Analysis of ICC, NCC, and OCC in the MBs of NE adults and 15 -d-old bees revealed significant changes in expression of Amdop1 (LMM, $P<0.0001$ ) (Fig. 4A) and Amdop2 (LMM, $P=$ 0.0022 ) (Fig. 4B) early in adult life. Levels of Amdop1 expression in young bees did not vary significantly across the three subpopulations of MB neurons (LMM, $P=0.3093$ ), but in all three cell groups Amdop1 expression levels were lower in 15-d-olds than in NE bees (Fisher's LSD, $P<0.05$ ). No significant interaction was identified in this data set between cell type and age (LMM, $P=$ 0.141). Amdop2 expression levels (Fig. 4B), like those of Amdop1 (Fig. 4A), were significantly higher in the ICC of NE adults than in the ICC of 15 -d-olds (Fisher's LSD, $P<0.05$ ). In contrast to Amdop1, however, levels of expression of Amdop2 tended to be lower in OCC and NCC of NE bees than in 15-d-olds. While differences in Amdop2 expression levels across the three subpopulations of Kenyon cells were not statistically significant (LMM, $P=$ 0.1439 ), our analysis identified a significant interaction between cell type and age in levels of expression of Amdop2 in the MBs of young (NE and 15-d-old) bees (LMM, $P<0.0001$ ).

In contrast to Amdop1 and Amdop2, levels of expression of Amdop3 in MB Kenyon cells early in adult life were clearly influenced by cell type (LMM, $P<0.0001)$, and a strong interaction was identified between cell type and age (LMM, $P<0.0001)$. In NCC, levels of Amdop3 expression were significantly higher in 15 -d-olds than in NE bees (Fisher's LSD, $P<0.05$ ), whereas in the OCC and ICC of NE bees and 15-d-olds, Amdop3 expression levels were remarkably similar (Fig. 4C). A strong overall trend suggesting that levels of Amoa1 expression in the MBs may be influenced by age and/or cell type encouraged us to undertake post hoc analyses also on data obtained for Amoa1 (Fig. 4D). While Amoa1 expression levels in the OCC of 15 -d-olds were lower than those detected in the OCC of NE bees (Fisher's LSD, $P<0.05$ ), no agerelated differences in the levels of expression of this gene were detected in NCC or ICC. Analysis of the data obtained for Amoa1 confirmed a significant overall effect of cell type on levels of expression of Amoa1 (LMM, $P<0.0001$ ) and, in addition, a strong interaction between cell type and age (LMM, $P=0.0045)$.

Amine-receptor gene expression and the shift to foraging Comparisons were made also between levels of amine-receptor gene expression in the ICC and NCC of 6 -d-old bees and pollen foragers (Fig. 5). While the results revealed few age-related differences in this data set (Fig. 5A-D), clear differences were apparent between the levels of gene expression detected in the two subpopulations of MB neurons. In 6-d-olds (Fisher's LSD, $P<0.05$ ) and in pollen foragers (Fisher's LSD, $P<0.05$ ), levels of expression of Amdop3 were significantly higher in NCC than in ICC, whereas levels of expression of Amoa1 were higher in ICC than in NCC, both in 6-d-olds (Fisher's LSD, $P<0.05$ ) and in pollen foragers (Fisher's LSD, $P<0.05$ ). In contrast to Amdop3 and Amoa1, levels of Amdop1 expression in ICC and NCC were remarkably similar in 6-d-old bees and in pollen foragers (Fig. 5A). The same was true of levels of Amdop2 expression in ICC and NCC of 6-d-old bees (Fisher's LSD, $P<0.05$ ). However, in pollen foragers, Amdop2 expression was higher in ICC than in NCC (Fisher's LSD, $P<$ 0.05 ). Arguably the most complex changes in gene expression at the level of the MB were those detected for Amdop2 (cf. Fig. 4 and Fig. 5).

\section{Discussion}

Our data show that each of the genes investigated in this study exhibits a unique pattern of expression in the MBs, a property that generates striking differences in the expression of amine-receptor genes across subpopulations of $\mathrm{MB}$ neurons. In light of this
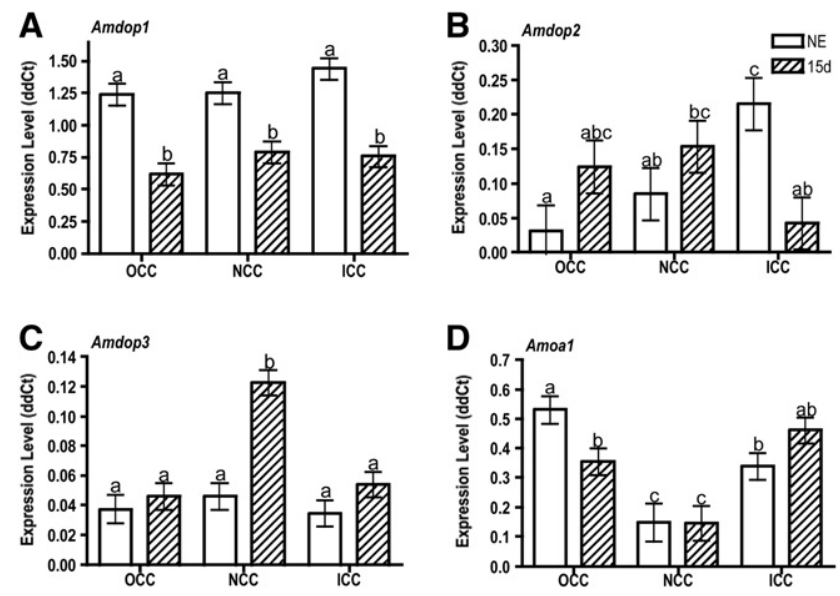

Figure 4. Amine-receptor transcript abundance in samples of lasercapture microdissected inner compact cells (ICC), noncompact cells (NCC), and outer compact cells (OCC) from newly emerged bees (open columns) and 15-d-old bees (hatched columns). Bars indicate the mean \pm standard error. Statistics (LMM): $(A)$ Amdop1, age $P<0.0001$, cell type $P=0.3093$, interaction $P=0.1439$; $(B)$ Amdop2, age $P=$ 0.0022 , cell type $P=0.1439$, interaction $P<0.0001$; (C) Amdop3, age $P=0.1352$, cell type $P<0.0001$, interaction $P<0.0001 ;(D)$ Amoa1, age $P<0.0672$, cell type $P<0.0001$, interaction $P=0.0045$. Letters above the bars indicate significant differences between groups. Groups sharing a letter are not significantly different (Fisher's LSD, $P \leq 0.05$ ). 

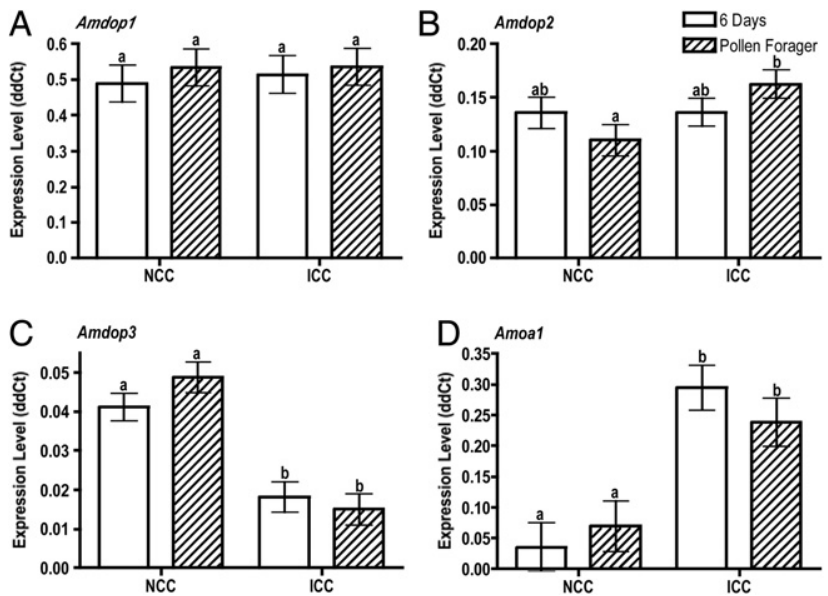

Figure 5. Amine-receptor transcript abundance in inner compact cells (ICC), noncompact cells (NCC), and outer compact cells (OCC) from 6 -d-old bees (open columns) and pollen foragers (hatched columns). Bars indicate mean values \pm standard error. Statistics (LMM): $(A)$ Amdop1, age $P=0.7310$, cell type $P=0.5256$, interaction $P=0.0 .6720$; (B) Amdop2, age $P=0.6028$, cell type $P=0.0004$, interaction $P=$ 0.1866 ; $(C)$ Amdop3, age $P=0.1310$, cell type $P=0.9292$, interaction $P=0.0252 ;(D)$ Amoa 1, age $P=0.2464$, cell type $P<0.0001$, interaction $P=0.0776$. Bars that do not share a letter differ significantly (Fisher's LSD, $P \leq 0.05)$.

heterogeneity, it is, perhaps, unsurprising that shifts in gene expression in whole-brain samples proved to be a poor indicator of changes occurring in the MB of the brain. Differential expression of amine-receptor genes at the level of the MBs is, nonetheless, consistent with a growing body of evidence that subpopulations of Kenyon cells can play distinctly different roles. In Drosophila, for example, transmission from $\alpha^{\prime} / \beta^{\prime}$-type MB neurons is required during learning and early memory consolidation in the fly (Keene et al. 2006; Krashes et al. 2007), whereas transmission from a different subpopulation of $\mathrm{MB}$ neurons ( $\alpha / \beta \mathrm{MB}$ neurons) appears to be critical for memory retrieval (Dubnau et al. 2001; McGuire et al. 2001; Krashes et al. 2007). Memory traces with different formation and decay kinetics appear to be supported also by different subpopulations of MB neurons (e.g., Zars et al. 2000; Isabel et al. 2004; Blum et al. 2009; Akalal et al. 2010), with different branches of MB neurons also exhibiting distinct functional properties (e.g., Yu et al. 2006; Akalal et al. 2010, 2011). The results of the present investigation suggest that in bees the functional heterogeneity of MB neurons is supported, at least in part, by the differential expression of amine-receptor genes. Heterogeneity of MB function in honeybees is also apparent from in situ hybridization studies showing differential mRNA expression of the inositol 1,4,5-triphosphate (Ip3) receptor (Takeuchi et al. 2002), ecdysone receptor AmEcR-A (Takeuchi et al. 2007), the nuclear receptor ultraspiracle AmUSP (Velarde et al. 2006), a number of ecdysteroid-regulated genes (Paul et al. 2006; Yamazaki et al. 2006), and the royal jelly protein RJP-3 (Kucharski et al. 1998).

From studies using antibodies raised against the Drosophila DA receptors $\mathrm{dDA} 1$ and $\mathrm{DAMB}$, the dopamine receptors in the fly appear to be evenly distributed across the lobes of the MBs (Han et al. 1996; Kim et al. 2003, 2007). However, the large variations in gene transcript levels across Kenyon cell subpopulations identified in the present study suggest that this is unlikely to be the case in bees. AmDOP1 receptors may be a notable exception. In contrast to the other genes examined in this study, levels of Amdop 1 transcript were remarkably similar across all three major subpopulations of MB neurons in the bee. The Drosophila ortholog of $A m D O P 1, \mathrm{dDA} 1$ has been strongly implicated in aversive olfac- tory memory formation (Kim et al. 2007; Selcho et al. 2009; Seugnet et al. 2009), as has DAMB, the Drosophila orthologue of AmDOP2 (Selcho et al. 2009; Seugnet et al. 2009), and in bees, antagonists that block $A m D O P 1$ and $A m D O P 2$ receptor function have been found to block aversive learning (Vergoz et al. 2007).

Interestingly, levels of Amoa1 expression in the brain show a strong correlation with the transition to foraging (present investigation), as do levels of OA in the brain (Schulz and Robinson 1999; Wagener-Hulme et al. 1999; Barron and Robinson 2005). OA plays an important role in reward reinforcement in insects (Menzel and Müller 1996; Hammer and Menzel 1998; Schwärzel et al. 2003; Schroll et al. 2006; Honjo and Furukubo-Tokunaga 2009), and in honeybees, the knockdown of $A m \mathrm{OA} 1$ receptor expression using RNA interference has been found to impair the recall of appetitive memories, as well as their acquisition (Farooqui et al. 2003). The proportion of bees that can be trained to associate an odor with a food reward tends to be lower in young bees $(<1 \mathrm{wk}$ postadult emergence) than in bees of foraging age (Morgan et al. 1998; Behrends and Scheiner 2009). It is tempting to speculate that the changes in amine-receptor gene expression identified in the MBs during the first $2 \mathrm{wk}$ of adult life contribute to the shifts in learning performance observed during this period. Changes in Amdop3 expression levels in NCC of the MBs were particularly striking; however, Amdop1, Amdop2, and Amoa1 expression levels also changed dramatically in some populations of Kenyon cells during this early time window. While shifts in learning performance might be expected during this early critical period, further work is required to provide a causal link between the shifts in amine-receptor gene expression and changes at the behavioral level. In addition, future studies using single cohort colonies (see Robinson 1992; Jassim et al. 2000) to generate precocious foragers and reverted nurses may help to disentangle the effects of age vs. behavior on gene expression changes such as those observed in this study.

The results of this study highlight a need to incorporate information about the differential expression of amine-receptor genes and the plasticity that exists at this level into future models of $\mathrm{MB}$ function. We have shown that, in bees, the three major Kenyon cell subpopulations exhibit distinct DA and OA receptor gene expression profiles and that there is significant spatial and temporal plasticity in the levels of expression of amine-receptor genes in the MBs of the bee. Analysis of predictable shifts in receptor expression promises insights into the functional significance of subpopulations of MB neurons and the role of the amine receptors in this important learning center of the brain.

\section{Materials and Methods}

\section{Selection of age groups}

To determine which age groups to examine in detail, we began by examining age-related changes in levels of expression of amine-receptor genes in the whole brain of worker bees. Three honeybee colonies permanently housed at the University of Otago Department of Zoology were used to source brood frames with emerging adult worker bees. Brood frames were held overnight in a humidified incubator at $34^{\circ} \mathrm{C}$. The following morning, bees that had emerged overnight were collected (typically 100200 bees), cold-anesthetized, and marked on the thorax with nontoxic acrylic paint. Once the marked bees had recovered from chilling, they were returned to their parent colony for $2,4,6$, or $15 \mathrm{~d}$. Newly emerged bees (NE) were obtained from frames cleared at 8:30 a.m. and then left for $1.5-2 \mathrm{~h}$ to accumulate new bees. Pollen foragers were captured at the hive entrance and identified by the presence of full pollen baskets on the hind legs. Whole-brain samples were collected from NE, 2-d-old, 4-d-old, 15 -d-old, and pollen forager bees ( 10 bees/sample). To determine how consistent changes in expression were from year to year and 

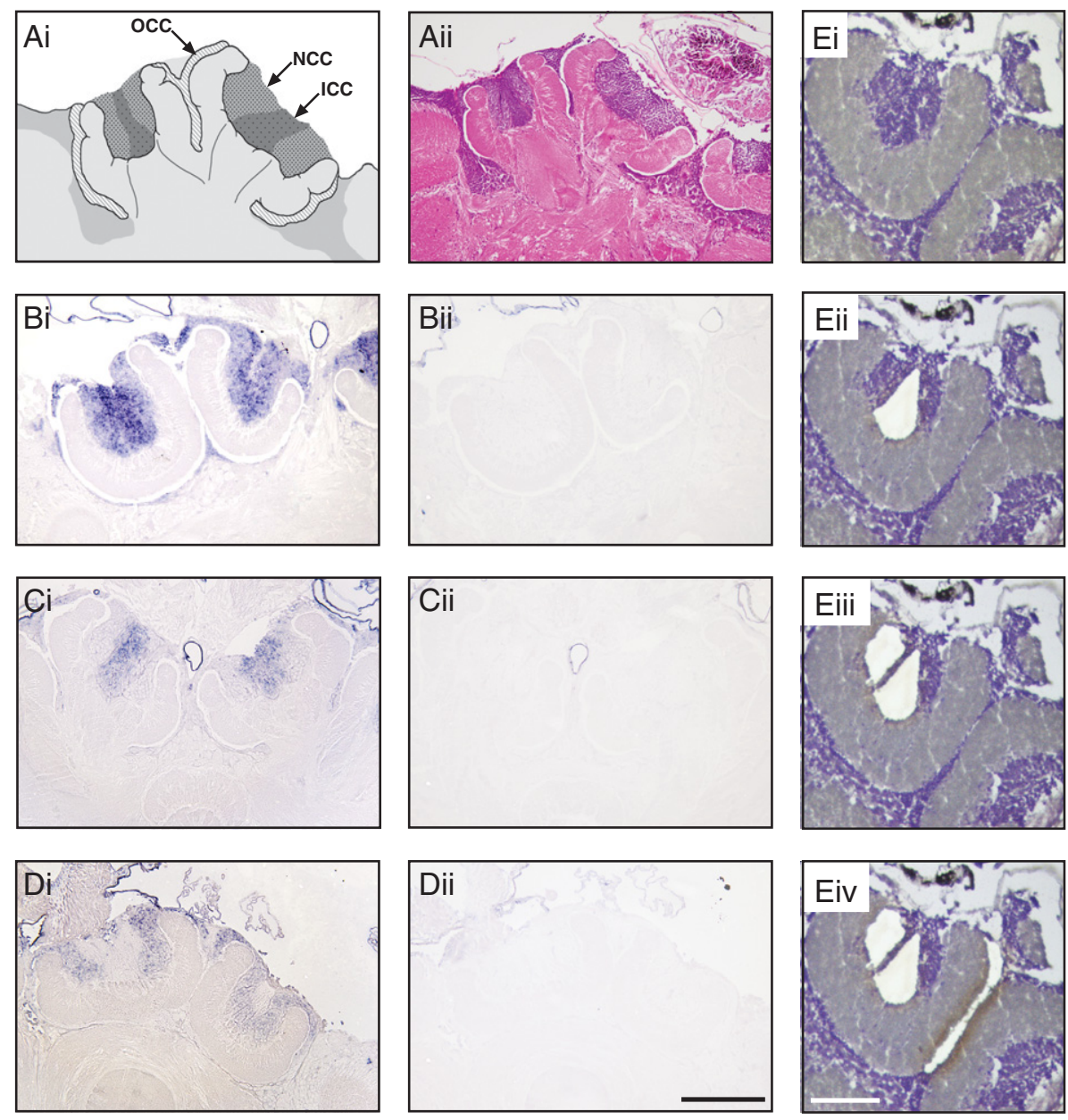

Figure 6. Expression of DA receptor genes across subpopulations of MB Kenyon cells examined using in situ hybridization. A schematic diagram (Ai) and histological section stained with haematoxylin and eosin (Aii) show the structure of the MB and location of inner-compact cells (ICC), noncompact cells (NCC), and outer compact cells (OCC). Micrographs showing in situ hybridization for the DA receptor genes Amdop1 (BI), Amdop2 (Ci), and Amdop3 (DI) in worker bee MB. Controls showing staining with sense probes for Amdop1 (Bii), Amdop2 (Cii), and Amdop3 (Dii), respectively. A representative cresyl violet-stained section prepared for laser-capture microdissection is shown in E. Sequential dissection of ICC, NCC, and OCC is illustrated in Eii-Eiv, respectively. Scale bars $=100 \mu \mathrm{m}$.

whether changes in expression could be detected using individual brains rather than pooled tissue, a second set of samples was collected and analyzed the following summer. During the second summer, whole brains were collected from NE bees, 6-d-olds, and pollen foragers, and the brain of each bee was analyzed separately.

\section{Real-time quantitative PCR}

Real-time quantitative PCR (qPCR) was used to investigate age-related changes in levels of expression of amine-receptor genes in whole-brain samples, as well as in subpopulations of MB neurons. Whole brains were dissected as quickly as possible, taking care to remove eye pigment and glandular tissue surrounding the brain. The brains were rinsed in bee saline $(154 \mathrm{mM} \mathrm{NaCl}$, $2 \mathrm{mM} \mathrm{NaH}_{2} \mathrm{PO}_{4}, 5.5 \mathrm{mM} \mathrm{Na}_{2} \mathrm{HPO}_{4}, \mathrm{pH} 7.2$ ), frozen on dry ice, and stored at $-80^{\circ} \mathrm{C}$ until further processing. Total RNA was extracted by homogenization of brain tissue in Trizol and isolated using Micro-Midi purification columns (Invitrogen). RNA concentrations were measured using a NanoDrop ND-100 spectrophotometer (NanoDrop Technologies). qPCR analysis was performed as previously described (Vergoz et al. 2009). Briefly, $100 \mathrm{ng}$ of RNA from individual brains or $200 \mathrm{ng}$ of RNA from samples of pooled brains was reverse-transcribed using VILO Supercript (Invitrogen). Gene-specific amplification products were generated using
ExpressSYBR GreenER qPCR SuperMix (Invitrogen) and genespecific primer pairs. Assay efficiencies were derived from standard curves generated using cDNA reverse-transcribed from a pool of the experimental RNA, or from a random whole-brain sample if cDNA was limited. Primer pairs, assay efficiencies, and melting product temperatures are provided in Table 1. Receptor transcript abundances were determined using the $\Delta \Delta \mathrm{Ct}$ method with assay efficiencies incorporated in the following formula: Normalized $=\left(1+\right.$ Efficiency target $\left.^{-\Delta \text { Ct target }}\right) /(1+$ Efficiency reference, $\left.^{-\Delta \mathrm{Ct} \text { reference }}\right)$. For whole-brain analysis, transcript levels were normalized using the geometric mean of two reference genes, ribophorin II (Rpn2) and ribosomal protein s8 (Rps8). Using the software packages geNorm (Vandesompele et al. 2002), BestKeeper (version 1; Pfaffl et al. 2004), and NormFinder (version 0.953; Andersen et al. 2004), these reference genes were found to be the most stable combination based on a selection of six candidates, which also included 18S, ribosomal protein 49 (rp49), elongation factor-1 alpha (ef1 $\alpha)$, and hydroxymethylbilane synthase (hmbs) (see Table 2). Generally triplicates, but occasionally duplicates, were run of each sample.

\section{In situ hybridization}

In situ hybridization was used to examine the spatial pattern of expression of DA receptor genes across subpopulations of $\mathrm{MB}$ 
Table 1. Real-time qPCR primer designs and assay parameters

\begin{tabular}{|c|c|c|c|}
\hline Gene & Primer designs & $\begin{array}{l}\text { RE } \\
(\%)\end{array}$ & $\begin{array}{l}\mathrm{MP} \\
\left({ }^{\circ} \mathrm{C}\right)\end{array}$ \\
\hline Amdop1 & $\begin{array}{l}\text { 5'- TGAACGATCTCCTCGGCTAT (forward) } \\
\text { 5'- ACCCAACGACCGTATCTCAG (reverse) }\end{array}$ & 90 & 84 \\
\hline Amdop2 & $\begin{array}{l}\text { 5'- GGATCAACAGCGGAATGAAT (forward) } \\
\text { 5'- GCGATCTTTGACTCGGTTT (reverse) }\end{array}$ & 97 & 86 \\
\hline Amdop3 & $\begin{array}{l}\text { 5'- CCATCTTCAATCTCGTAGCAATC (forward) } \\
5^{\prime} \text { - AGACCAACAGTATCGTCAACCAC (reverse) }\end{array}$ & 94 & 80 \\
\hline Amoa1 & $\begin{array}{l}\text { 5'- GAACGCCATCCAAGTGTTCT (forward) } \\
\text { 5'- GTGCTTCCAACCCTGTTGAT (reverse) }\end{array}$ & 100 & 84.5 \\
\hline 185 & $\begin{array}{l}\text { 5'- ACCCTGCTAAATAGACGTAACTTATGG } \\
\text { 5'- GATTTGTTTGACGTTGGTAGTAAAAACC }\end{array}$ & 90 & 80 \\
\hline Rpn2 & $\begin{array}{l}\text { 5'- CGCCTGTAATGGAAACTGAAA (forward) } \\
5^{\prime} \text { - ACACGTTCTTGTTGCTCACG (reverse) }\end{array}$ & 97 & 79 \\
\hline Rps8 & $\begin{array}{l}\text { 5'- ACGAGGTGCGAAACTGACTGA (forward) } \\
\text { 5'- GCACTGTCCAGGTCTACTCGA (reverse) }\end{array}$ & 97 & 80 \\
\hline$e f 1 \alpha$ & $\begin{array}{l}\text { 5'- AAGAGCATCAAGAGCGGAGA (forward) } \\
\text { 5'- CACTCTTAATGACGCCCACA (reverse) }\end{array}$ & 91 & 87.2 \\
\hline rp49 & $\begin{array}{l}\text { 5'- GGACAATATTTGATGCCCAAT (forward) } \\
5^{\prime} \text { - CATGAGCAATTTCAGCACAA (reverse) }\end{array}$ & 96 & 76.5 \\
\hline Hmbs & $\begin{array}{l}\text { 5'- CCTGATGATGGAGAACCTC (forward) } \\
\text { 5'- CGAGTTCAGCACCCAAA (reverse) }\end{array}$ & 91 & 78.5 \\
\hline
\end{tabular}

(RE) Reaction efficiency, (MP) product melting point.

neurons and to determine how best to ensure that equivalent populations of cells were being examined in each age group (Fig. 6). Whole brains were dissected and fixed in $4 \%$ buffered paraformaldehyde at room temperature for $2 \mathrm{~h}$ and then at $4^{\circ} \mathrm{C}$ for an additional $20 \mathrm{~h}$. Brains were then dehydrated through a graded series of ethanol and xylene, then embedded in paraffin. Sections of brain tissue ( $8 \mathrm{~mm}$ thick) were mounted on polysine slides (BDH Laboratory Supplies), and in situ hybridization was performed using digoxygenin (DIG)-labeled ribo-probes according to a protocol similar to that described by Braissant and Wahli (1998). Probes for Amdop1, Amdop2, and Amdop3 were synthesized as described previously (Beggs et al. 2005). Hybridization was performed using ribo-probes at a concentration of $1 \mathrm{mg} / \mathrm{mL}$ as this was found to produce staining of a moderate intensity, which enhanced subtle differences in levels of receptor-gene expression between subpopulations of $\mathrm{MB}$ neurons. Hybridized probes were detected immunologically using anti-DIG antibody. The antibody was diluted 1:5000 and applied to sections for $2 \mathrm{~h}$. The sections were then stained with 4-nitro blue tetrazolium chloride $(450 \mu \mathrm{g} / \mathrm{mL})$ and X-phosphate/5-bromo-4-chloro-3indolyl-phosphate $(175 \mu \mathrm{g} / \mathrm{mL})$ (Roche Molecular Biochemicals) for $16-18 \mathrm{~h}$ at room temperature. Staining was stopped with two 10 -min washes in distilled water. Nonspecific staining was removed by washing in $95 \%$ ethanol for $30 \mathrm{~min}$. Sections were rehydrated in distilled water and mounted using Aquamount (BDH Laboratory Supplies). As staining confirmed that the three major subpopulations of MB neurons showed marked differences in expression of the three DA receptor genes, these subpopulations of cells were targeted using laser-capture microdissection techniques.

\section{Laser-capture microdissection}

Laser-capture microdissection (LMD) was used to sample MB Kenyon cells and specifically, inner compact cells, outer compact cell, and noncompact cells. The morphology and developmental characteristics of these three distinct populations of neurons have been described in detail by Farris et al. (1999, 2004). Brains used for LMD were dissected, placed in Tissue Tek (Sukura), and promptly frozen on dry ice. Serial sections $(12 \mu \mathrm{m})$ were taken from areas of the brain in which the three populations of $\mathrm{MB}$ intrinsic neurons were most clearly apparent (Fig. 6). The sections were briefly thaw-mounted onto $2-\mu \mathrm{m}$ polyethylene naphthalate membrane slides (Leica), immediately refrozen on dry ice, and stored at $-80^{\circ} \mathrm{C}$ until further processing. Prior to the capture of cell populations, the sections were thawed, fixed in $75 \%$ ethanol (30 sec), and briefly washed in MilliQ water and then in PBS $(10 \mathrm{sec})$. The sections were then stained in $0.5 \%$ cresyl violet acetate in $0.1 \mathrm{M} \mathrm{NaAcetate}$ buffer $(30 \mathrm{sec})$ and briefly rinsed twice in MilliQ water before being dehydrated in 75\% ethanol (30 sec), 95\% ethanol (30 sec), and 100\% ethanol (1 min), followed by Xylene (5 min). The slides were then air dried for $5 \mathrm{~min}$ and used immediately for laser capture. During all steps, RNase-free solutions and handling techniques were used. Using the Leica AS LMD, a laser beam was used to isolate samples from each subpopulation of MB neurons, as shown in Figure 6E. Each sample included cells captured from between eight and 16 sections of the lateral and medial mushroom body calyces of one bee. Samples of ICC, NCC, and OCC were isolated from 3-5 bees per experimental group. Isolated cells were immediately frozen on dry ice, and RNA was isolated from the cells as soon as possible using an RNeasy Micro Kit (Qiagen). RNA quality and quantity were assessed using the 2100 expert bioanalyzer, a pico assay chip, and reagents (Agilent) according to the manufacturer's protocols. As reported by Winnebeck et al. (2010), denatured honeybee RNA does not have a visible $28 \mathrm{~S}$ rRNA peak due to the presence of a hidden break that leads to fragmentation of the $28 \mathrm{~S}$ rRNA. To adjust for this, the $18 \mathrm{~S}: 28 \mathrm{~S}$ threshold ratio anomaly setting was manually overridden to enable integrity values to be obtained. These were typically $\geq 6$ for laser-captured RNA samples. Using 2 ng RNA from each sample, levels of expression of amine-receptor genes were analyzed using qPCR. Triplicates (or occasionally duplicates) were run of each sample, and transcript levels for laser capture microdissection experiments were normalized using ef $1 \alpha$ which was found to be among the most stable in these samples (see Table 3).

\section{Statistical methods}

All statistical analyses were conducted in the R environment (version 2.12.2; R Development Core Team 2011). LMM performed using the $\mathrm{R}$ function lmer in the package lme4 (R package version 0.999375-42, http://CRAN.R-project.org/package=lme4) was used to examine differences in levels of receptor-gene expression between age groups and between subpopulations of Kenyon cells (fixed factors); bee identities were included as a random factor. The use of LMM enabled us to increase statistical power by incorporating variation in replicates of the same sample; in other words, LMM used each replicate as a data point while at the same time accounting for nonindependence of related replicates (Nakagawa and Hauber 2011). It is noted that the calculation of the degrees of freedom $(d f)$ required for obtaining a $P$ value in LMM is not straightforward (Bolker et al. 2009). Therefore, we provide alternative $P$ values estimated by Markov Chain Monte Carlo (MCMC) sampling, implemented in the R function pvals. $f n c$, in the package languageR for all LMM analyses (Baayen et al. 2008).

Table 2. Rankings of reference gene stability in the aging honeybee brain according to GeNorm, NormFinder, and BestKeeper analysis

\begin{tabular}{|c|c|c|c|c|c|c|}
\hline \multirow[b]{2}{*}{ Stability } & \multicolumn{3}{|c|}{$\begin{array}{c}\text { Adult age series with reduced time } \\
\text { points }(n=30)\end{array}$} & \multicolumn{3}{|c|}{ Full adult age series $(n=25)$} \\
\hline & GeNorm $^{a}$ & Normfinder & BestKeeper & GeNorm $^{a}$ & Normfinder & BestKeeper \\
\hline Highest & $\begin{array}{l}\text { Rpn2 (0.295) } \\
\text { Rps8 }(0.246) \\
18 \mathrm{~S}(0.300) \\
\text { rp49 }(0.313) \\
\text { ef1 } \alpha \\
\text { hmbs }\end{array}$ & $\begin{array}{l}\text { Hmbs }(0.138)^{b} \\
\text { Rpn2 }(0.170) \\
\text { Rps8 }(0.236)^{b} \\
18 S(0.276) \\
\operatorname{rp} 49(0.365) \\
\text { ef1 } \alpha(0.379)\end{array}$ & $\begin{array}{l}18 \mathrm{~S} \\
\text { Rpn2 } \\
\text { Rps8 } \\
\text { rp49 } \\
\text { hmbs } \\
\text { ef1 } \alpha\end{array}$ & $\begin{array}{l}\text { Rpn2 (0.268) } \\
18 \mathrm{~S}(0.286) \\
\text { ef1 } \alpha(0.301) \\
\text { Rps8 }(0.331) \\
\text { rp49 } \\
\text { hmbs }\end{array}$ & $\begin{array}{l}\text { Rpn2 }(0.098)^{\mathrm{b}} \\
18 \mathrm{~S}(0.115) \\
\text { Rps8 }(0.140)^{\mathrm{b}} \\
\text { ef1 } \alpha(0.147) \\
\text { rp49 }(0.178) \\
\text { hmbs }(0.206)\end{array}$ & $\begin{array}{l}18 \mathrm{~S} \\
\text { Rpn2 } \\
\text { ef1 } \alpha \\
\text { Rps8 } \\
\text { rp49 } \\
\text { hmbs }\end{array}$ \\
\hline
\end{tabular}

Stability values and $M$ values are shown in parentheses.

${ }^{\mathrm{a}} \mathrm{M}$ values shown indicate values calculated for the final top four genes only.

${ }^{b}$ Best combination of two genes indicated by Normfinder. 
Table 3. Rankings of reference gene stability in laser-capture dissected Kenyon cells of newly emerged (NE) and pollen forager (PF) bees

\begin{tabular}{|c|c|c|c|}
\hline \multirow[b]{2}{*}{ Stability } & \multicolumn{2}{|c|}{ 6-d vs. PF LMD samples $(n=12)$} & \multirow[b]{2}{*}{ BestKeeper } \\
\hline & GeNorm $^{a}$ & Normfinder & \\
\hline Highest & $\begin{array}{l}\text { Rpn2 }(0.161) \\
\text { ef1 } \alpha(0.161) \\
18 S\end{array}$ & $\begin{array}{l}\text { Rpn2 }(0.076)^{b} \\
\text { ef1 } \alpha(0.078)^{b} \\
18 S(0.086)\end{array}$ & $\begin{array}{l}\text { Rps8 } \\
\text { Rpn2 } \\
185\end{array}$ \\
\hline Lowest & Rps8 & Rps8 (0.143) & ef1 $\alpha$ \\
\hline
\end{tabular}

Stability values and $\mathrm{M}$ values are shown in parentheses.

${ }^{\mathrm{a}} \mathrm{M}$ values shown indicate values calculated for the final top two genes only.

${ }^{b}$ Best combination of two genes indicated by Normfinder.

For post-hoc analyses of pairwise differences, we used Fisher's least significant difference implemented by the R function, glht in the package, multcomp (Bretz et al. 2011).

\section{Acknowledgments}

We thank Dr. Peter Dearden for his helpful comments regarding the selection of reference genes for normalizing real-time qPCR data. We also thank Kim Garrett for maintaining our honeybee colonies, Ken Miller for his help in the production of figures, and Karen Judge and Matthew Downes for the maintenance of laboratory equipment. This work was funded by the Royal Society of New Zealand Marsden Fund Grant UOO0910.

\section{References}

Agarwal M, Giannoni Guzman M, Morales-Matos C, Del Valle Diaz RA, Abramson CI, Giray T. 2011. Dopamine and octopamine influence avoidance learning of honey bees in a place preference assay. PLOS ONE 6: e25371. doi: 10.1371/journal.pone.0025371.

Akalal DB, Yu D, Davis RL. 2010. A late-phase, long-term memory trace forms in the gamma neurons of Drosophila mushroom bodies after olfactory classical conditioning. J Neurosci 30: 16699-16708.

Akalal DB, Yu D, Davis RL. 2011. The long-term memory trace formed in the Drosophila alpha/beta mushroom body neurons is abolished in long-term memory mutants. J Neurosci 31: 5643-5647.

Andersen CL, Jensen JL, Orntof TF. 2004. Normalization of real-time quantitative reverse transcription-PCR data: A model-based variance estimation approach to identify genes suited for normalization, applied to bladder and colon cancer data sets. Cancer Res 64: 5245-5250.

Baayen RH, Davidson DJ, Bates DM. 2008. Mixed-effects modeling with crossed random effects for subjects and items. J Mem Lang 59: $390-412$.

Barron AB, Robinson GE. 2005. Selective modulation of task performance by octopamine in honey bee (Apis mellifera) division of labour. J Comp Physiol A 191: 659-668.

Beggs KT, Mercer AR. 2009. Dopamine receptor activation by honey bee queen pheromone. Curr Biol 19: 1206-1209.

Beggs KT, Hamilton IS, Kurshan PT, Mustard JA, Mercer AR. 2005. Characterization of a D2-like dopamine receptor (AmDOP3) in honey bee, Apis mellifera. Insect Biochem Mol Biol 35: 873-882.

Beggs KT, Tyndall JD, Mercer AR. 2011. Honey bee dopamine and octopamine receptors linked to intracellular calcium signaling have a close phylogenetic and pharmacological relationship. PLOS ONE 6: e26809. doi: 10.1371/journal.pone.0026809.

Behrends A, Scheiner R. 2009. Evidence for associative learning in newly emerged honey bees (Apis mellifera). Anim Cogn 12: 249-255.

Blenau W, Erber J, Baumann A. 1998. Characterization of a dopamine D1 receptor from Apis mellifera: Cloning, functional expression, pharmacology, and mRNA localization in the brain. J Neurochem 70: $15-23$.

Blum AL, Li W, Cressy M, Dubnau J. 2009. Short- and long-term memory in Drosophila require cAMP signaling in distinct neuron types. Curr Biol 19: $1341-1350$

Bolker BM, Brooks ME, Clark CJ, Geange SW, Poulsen JR, Stevens MHH, White JSS. 2009. Generalized linear mixed models: A practical guide for ecology and evolution. Trends Ecol Evol 24: 127-135.

Braissant O, Wahli W. 1998. A simplified in situ hybridization protocol using nonradioactively labelled probes to detect abundant and rare mRNAs on tissue sections. Biochemica 1: 10-16.
Bretz F, Hothorn T, Westfall P. 2011. Multiple comparisons using R. Chapman \& Hall/CRC, Boca Raton, FL.

Claridge-Chang A, Roorda RD, Vrontou E, Sjulson L, Li H, Hirsh J, Miesenböck G. 2009. Writing memories with light-addressable reinforcement circuitry. Cell 139: 405-415.

Clark MC, Baro DJ. 2007. Arthropod D2 receptors positively couple with cAMP through the Gi/o protein family. Comp Biochem Physiol B 146: 9-19.

Davis RL. 2005. Olfactory memory formation in Drosophila: From molecular to systems neuroscience. Annu Rev Neurosci 28: 275-302.

Dubnau J, Grady L, Kitamoto T, Tully T. 2001. Disruption of neurotransmission in Drosophila mushroom body blocks retrieval but not acquisition of memory. Nature 411: 476-480.

Farooqui T, Robinson K, Vaessin H, Smith BH. 2003. Modulation of early olfactory processing by an octopaminergic reinforcement pathway in the honeybee. J Neurosci 23: 5370-5380.

Farris SM, Robinson GE, Davis RL, Fahrbach SE. 1999. Larval and pupal development of the mushroom bodies in the honey bee, Apis mellifera. J Comp Neurol 414: 97-113.

Farris SM, Abrams AI, Strausfeld NJ. 2004. Development and morphology of class II Kenyon cells in the mushroom bodies of the honey bee, Apis mellifera. J Comp Neurol 474: 325-339.

Grohmann L, Blenau W, Erber J, Ebert PR, Strunker T, Baumann A. 2003. Molecular and functional characterization of an octopamine receptor from honeybee (Apis mellifera) brain. J Neurochem 86: 725-735.

Hammer M, Menzel R. 1998. Multiple sites of associative odor learning as revealed by local brain microinjections of octopamine in honeybees. Learn Mem 5: 146-156.

Han KA, Millar NS, Grotewiel MS, Davis RL. 1996. DAMB, a novel dopamine receptor expressed specifically in Drosophila mushroom bodies. Neuron 16: 1127-1135.

Hauser F, Cazzamali G, Williamson M, Blenau W, Grimmelikhuijzen CJ. 2006. A review of neurohormone GPCRs present in the fruitfly Drosophila melanogaster and the honey bee Apis mellifera. Prog Neurobiol 80: $1-19$.

Heisenberg M. 2003. Mushroom body memoir: From maps to models. Nat Rev Neurosci 4: 266-275.

Honjo K, Furukubo-Tokunaga K. 2009. Distinctive neuronal networks and biochemical pathways for appetitive and aversive memory in Drosophila larvae. J Neurosci 29: 852-862.

Humphries MA, Mustard JA, Hunter SJ, Mercer A, Ward V, Ebert PR. 2003. Invertebrate D2 type dopamine receptor exhibits age-based plasticity of expression in the mushroom bodies of the honeybee brain. I Neurobiol 55: $315-330$.

Isabel G, Pascual A, Preat T. 2004. Exclusive consolidated memory phases in Drosophila. Science 304: 1024-1027.

Jassim O, Huang ZY, Robinson GE. 2000. Juvenile hormone profiles of worker honey bees, Apis mellifera, during normal and accelerated behavioural development. J Insect Physiol 46: 243-249.

Keene AC, Waddell S. 2007. Drosophila olfactory memory: Single genes to complex neural circuits. Nat Rev Neurosci 8: 341-354.

Keene AC, Krashes MJ, Leung B, Bernard JA, Waddell S. 2006. Drosophila dorsal paired medial neurons provide a general mechanism for memory consolidation. Curr Biol 16: 1524-1530.

Kim YC, Lee HG, Seong CS, Han KA. 2003. Expression of a D1 dopamine receptor dDA1/DmDOP1 in the central nervous system of Drosophila melanogaster. Gene Expr Patterns 3: 237-245.

Kim YC, Lee HG, Han KA. 2007. D1 dopamine receptor dDA1 is required in the mushroom body neurons for aversive and appetitive learning in Drosophila. J Neurosci 27: 7640-7647.

Krashes MJ, Keene AC, Leung B, Armstrong JD, Waddell S. 2007. Sequential use of mushroom body neuron subsets during Drosophila odor memory processing. Neuron 53: 103-115.

Krashes MJ, DasGupta S, Vreede A, White B, Armstrong JD, Waddell S. 2009. A neural circuit mechanism integrating motivational state with memory expression in Drosophila. Cell 139: 416-427.

Kucharski R, Maleszka R, Hayward DC, Ball EE. 1998. A royal jelly protein is expressed in a subset of Kenyon cells in the mushroom bodies of the honey bee brain. Naturwissenschaften 85: 343-346.

Kurshan PT, Hamilton IS, Mustard JA, Mercer AR. 2003. Developmental changes in expression patterns of two dopamine receptor genes in mushroom bodies of the honeybee, Apis mellifera. J Comp Neurol 466: $91-103$.

McGuire SE, Le PT, Davis RL. 2001. The role of Drosophila mushroom body signaling in olfactory memory. Science 293: 1330-1333.

Menzel R. 2001. Searching for the memory trace in a mini-brain, the honeybee. Learn Mem 8: 53-62.

Menzel R, Müller U. 1996. Learning and memory in honeybees: From behavior to neural substrates. Annu Rev Neurosci 19: 379-404.

Menzel R, Heyne A, Kinzel C, Gerber B, Fiala A. 1999. Pharmacological dissociation between the reinforcing, sensitizing, and 
response-releasing functions of reward in honeybee classical conditioning. Behav Neurosci 113: 744-754.

Mercer AR, Menzel R. 1982. The effects of biogenic-amines on conditioned and unconditioned responses to olfactory stimuli in the honeybee Apis mellifera. J Comp Physiol 145: 363-368.

Morgan SM, Butz Huryn VM, Downes SR, Mercer AR. 1998. The effects of queenlessness on the maturation of the honey bee olfactory system. Behav Brain Res 91: 115-126.

Mustard JA, Blenau W, Hamilton IS, Ward VK, Ebert PR, Mercer AR. 2003. Analysis of two D1-like dopamine receptors from the honey bee Apis mellifera reveals agonist-independent activity. Brain Res Mol Brain Res 113: $67-77$.

Mustard JA, Beggs KT, Mercer AR. 2005. Molecular biology of the invertebrate dopamine receptors. Arch Insect Biochem Physiol 59: 103-117.

Nakagawa S, Hauber ME. 2011. Great challenges with few subjects: Statistical strategies for neuroscientists. Neurosci Biobehav Rev 35: $462-473$.

Paul RK, Takeuchi H, Kubo T. 2006. Expression of two ecdysteroid-regulated genes, Broad-Complex and E75, in the brain and ovary of the honeybee (Apis mellifera L.). Zool Sci 23: 1085-1092.

Pfaffl MW, Tichopad A, Prgomet C, Neuvians TP. 2004. Determination of stable housekeeping genes, differentially regulated target genes, and sample integrity: BestKeeper-Excel-based tool using pair-wise correlations. Biotechnol Lett 26: 509-515.

R Development Core Team. 2011. R: A language and environment for statistical computing. R Foundation for Statistical Computing, Vienna, Austria.

Riemensperger T, Völler T, Stock P, Buchner E, Fiala A. 2005. Punishment prediction by dopaminergic neurons in Drosophila. Curr Biol 15: 1953-1960.

Robinson GE. 1992. Regulation of division of labor in insect societies. Annu Rev Entomol 37: 637-665.

Schroll C, Riemensperger T, Bucher D, Ehmer J, Völler T, Erbquth K, Gerber B, Hendel T, Nagel G, Buchner E, et al. 2006. Light-induced activation of distinct modulatory neurons triggers appetitive or aversive learning in Drosophila larvae. Curr Biol 16: 1741-1747.

Schulz DJ, Robinson GE. 1999. Biogenic amines and division of labor in honey bee colonies: Behaviorally related changes in the antennal lobes and age-related changes in the mushroom bodies. J Comp Physiol A 184: 481-488.

Schwärzel M, Monastirioti M, Scholz H, Friggi-Grelin F, Birman S, Heisenberg M. 2003. Dopamine and octopamine differentiate between aversive and appetitive olfactory memories in Drosophila. J Neurosci 23: 10495-10502.
Selcho M, Pauls D, Han KA, Stocker RF, Thum AS. 2009. The role of dopamine in Drosophila larval classical olfactory conditioning. PLoS ONE 4: e5897. doi: 10.1371/journal.pone.0005897.

Seugnet L, Galvin JE, Suzuki Y, Gottschalk L, Shaw PJ. 2009. Persistent short-term memory defects following sleep deprivation in a Drosophila model of Parkinson disease. Sleep 32: 984-992.

Takeuchi H, Fujiyuki T, Shirai K, Matsuo Y, Kamikouchi A, Fujinawa Y, Kato A, Tsujimoto A, Kubo T. 2002. Identification of genes expressed preferentially in the honeybee mushroom bodies by combination of differential display and cDNA microarray. FEBS Lett 513: 230-234.

Takeuchi H, Paul RK, Matsuzaka E, Kubo T. 2007. EcR-A expression in the brain and ovary of the honeybee (Apis mellifera L.). Zool Sci 24: 596-603.

Vandesompele J, De Preter K, Pattyn F, Poppe B, Van Roy N, De Paepe A, Speleman F. 2002. Accurate normalization of real-time quantitative RT-PCR data by geometric averaging of multiple internal control genes. Genome Biol 3: research0034.1-research0034.11.

Velarde RA, Robinson GE, Fahrbach SE. 2006. Nuclear receptors of the honey bee: Annotation and expression in the adult brain. Insect Mol Biol 15: $583-595$.

Vergoz V, Roussel E, Sandoz JC, Giurfa M. 2007. Aversive learning in honeybees revealed by the olfactory conditioning of the sting extension reflex. PLOS ONE 2: e288. doi: 10.1371/journal.pone. 0000288.

Vergoz V, McQuillan HJ, Geddes LH, Pullar K, Nicholson BJ, Paulin MG, Merce AR. 2009. Peripheral modulation of worker bee responses to queen mandibular pheromone. Proc Nat Acad Sci 106: 20930-20935.

Wagener-Hulme C, Kuehn JC, Schulz DJ, Robinson GE. 1999. Biogenic amines and division of labor in honey bee colonies. J Comp Physiol A 184: $471-479$.

Winnebeck EC, Millar CD, Warman GR. 2010. Why does insect RNA look degraded? J Insect Sci 10: 159. doi: 10.1673/031.010.14119.

Yamazaki Y, Shirai K, Paul RK, Fujiyuki T, Wakamoto A, Takeuchi H, Kubo T. 2006. Differential expression of HR38 in the mushroom bodies of the honeybee brain depends on the caste and division of labor. FEBS Lett 580: $2667-2670$.

Yu D, Akalal DB, Davis RL. 2006. Drosophila alpha/beta mushroom body neurons form a branch-specific, long-term cellular memory trace after spaced olfactory conditioning. Neuron 52: 845-855.

Zars T, Fischer M, Schulz R, Heisenberg M. 2000. Localization of a short-term memory in Drosophila. Science 288: 672-675.

Received December 20, 2011; accepted in revised form February 14, 2012. 


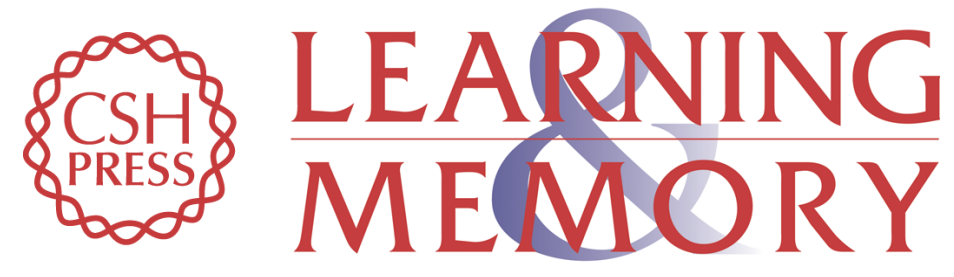

\section{Mushroom bodies of the honeybee brain show cell population-specific plasticity in expression of amine-receptor genes}

H. James McQuillan, Shinichi Nakagawa and Alison R. Mercer

Learn. Mem. 2012, 19:

Access the most recent version at doi:10.1101//m.025353.111

References This article cites 67 articles, 13 of which can be accessed free at: http://learnmem.cshlp.org/content/19/4/151.full.html\#ref-list-1

License

Email Alerting Receive free email alerts when new articles cite this article - sign up in the box at the Service top right corner of the article or click here. 